\section{PHYSICAL ACTIVITY LEVEL AND ENERGY EXPENDITURE ASSESSED BY ACCELEROMETRY IN 60Y+ BRAZILIAN SUBJECTS}

\author{
NIVIEL DE ATIVIDADEFISICA EGASTO ENERGÉTICO AVALIADOS PORACELEROMETRIA EMIDOSOS BRASILEIROS
}

NIVEL DEACTIVIDAD FISICA Y GASTO ENERGÉTICO EVALUADOS POR ACELEROMETRÍA EN ANCIANOS BRASILEÑOS

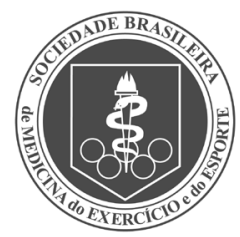

Original Article ARtigo Original Artículo Original
Luiz Antonio dos Anjos' (Physician),

Bruna de Andrade Messias da Silva' ${ }^{1}$ (Nutritionist),

Vivian Wahrlich'

(Nutritionist)

1. Universidade Federal Fluminense, Niterói, Rio de Janeiro, Brazil.

\section{Correspondence:}

Luiz Antonio dos Anjos.

Universidade Federal Fluminense,

Department of Social Nutrition

Laboratório de Avaliação

Nutricional e Funcional.

Rua Mario Santos Braga, 30, sala 415

Campus do Valonguinho, Niterói,

RJ, Brazil. 24020-140.

lanjos@id.uff.br

\begin{abstract}
Objective: To assess the physical activity level (PAL) and the total daily energy expenditure (EE-TDEE) in a sample of $\geq 60$ y subjects from Niterói, Rio de Janeiro, Brazil. Methods: A convenience sample of 88 subjects recruited from recreational physical activity programs wore an accelerometer around the waist for seven consecutive days for at least 10h/day. Minute-by-minute EE was estimated from the counts per minute (CPM) data, and the daily sum yielded the TDEE. PAL (TDEE/BMR) with BMR calculated with the FAO/WHO predictive equation and a population-specific equation. Body composition was assessed by DXA. Results: Mean age (SD) was 69.2 (5.8) years, the prevalence of overweight and obesity was 36.4 and $25.0 \%$, respectively, and excess body fat was $39.8 \%$. The subjects spent $600 \mathrm{~min} /$ day engaged in sedentary activities (CPM<100). Men engaged in 30min of moderate-to-vigorous physical activity (CPM $\geq 1,952)$ daily, on average. The subjects were active on 34.5 and $18.0 \%$ of the weekdays and weekend days with a 1,400 steps/day difference between these days. TDEE was 1,731.5 (348.7) and 1,356.3 (223.7) kcal/day depending on the BMR prediction equation used. Mean PAL was lower than the maintenance level. Conclusions: The high prevalence of sedentary activities and the low percentage of subjects who met the physical activity recommendations indicate that physical activity programs must be adjusted so that the enrolled subjects can meet the physical activity recommendations, preferably with the activities objectively monitored. Population-specific equations improve the final estimation of TDEE and PAL. Level of Evidence l; Diagnostic studies - Investigating a diagnostic test.
\end{abstract}

Keywords: Energy expenditure; Motor activity; Exercise.

\section{RESUMO}

Objetivo: Avaliar o nível de atividade fisica (NAF) e o gasto energético total diário (GETD) em uma amostra de idosos ( $\geq$ 60 anos) residentes no município de Niterói, Rio de Janeiro, Brasil. Métodos: Uma amostra de conveniência de 88 indivíduos recrutados em programas de atividade física usou acelerômetro na cintura durante sete dias consecutivos, por pelo menos 10 horas por dia. O GE por minuto foi estimado a partir de dados de contagem por minuto (CPM), cujo somatório diário forneceu o GETD. O NAF (GETD/TMB) foi calculado com a TMB estimada pela equação preditiva da FAO/WHO e por equação especifica para a população estudada. A composição corporal foi avaliada por DXA. Resultados: A média de idade (DP) foi de 69,2 (5,8) anos, a prevalência de sobrepeso e obesidade foide 36,4 e25,0\%, respectivamente, e o de excesso de gordura corporal foi 39,8\%. Os individuos passaram $600 \mathrm{~min}$.dia em atividades sedentárias (CPM < 100). Os homens realizaram, em média, 30 minutos de atividade física vigorosa a moderada (CPM $\geq 1.952$ ) diariamente. Os individuos foram ativos em 34,5\% e 18\% dos dias da semana enos fins de semana, respectivamente, com uma diferença de 1.400 passos/dia entre esses dias. O GETD foi de 1.731,5 (348,7) e 1.356,3 (223,7) kcal/dia, dependendo da equação preditiva da TMB usada. O NAFmédio foi inferior ao nivel de atividade de manutenção. Conclusão: A alta prevalência de atividades sedentárias e o baixo percentual de indivíduos que atenderam às recomendações de atividade física indicam que esses programas devem ser ajustados para que os individuos inscritos possam atender às recomendações, preferencialmente, com monitoramento objetivo. As equações populacionais específicas melhoram a estimativa final do GETD eNAF. Nível de Evidência l; Estudos diagnósticos - Investigação de um exame para diagnóstico.

Descritores: Ingestão de energia; Atividade motora; Saúde do idoso; Exercício.

\section{RESUMEN}

Objetivo: Evaluar el nivel de actividad física (NAF) y el gasto energético total diario (GETD) en una muestra de ancianos ( $\geq 60$ años) residentes en el municipio de Niterói, Rio de Janeiro, Brasil. Métodos: Una muestra de conveniencia de 88 individuos reclutados en programas de actividad física usó acelerómetro en la cintura durante siete días consecutivos, durante por lo menos 10 horas por día. El GE por minuto fue estimado a partir de datos de conteo por minuto (CPM), cuya sumatoria diaria suministró el GETD. EI NAF (GETD/TMB) fue calculado con la ecuación predictiva de FAO/WHO y por ecuación específica para la población estudiada. La composición corporal fue evaluada por DXA. Resultados: El promedio de edad (SD) fue de 69,2 (5,8) años, l a prevalencia de sobrepeso y obesidad fue de 36,4y25,0\%, respectivamente, y el de exceso de grasa corporal fue de 39,8\%. Los individuos pasaron $600 \mathrm{~min} /$ día en actividades sedentarias (CPM < 100). Los hombres realizaron, como promedio, 30 minutos de actividad física vigorosa a moderada (CPM $\geq 1.952)$ diariamente. Los individuos fueron activos en 34,5\% y 18\% de los días de la semana y en los fines de semana, respectivamente, con una diferencia de 1.400 pasos/día entre esos días. El GETD fue de 1.731,5 (348,7) y 1.356,3 $(223,7) \mathrm{kcal} / \mathrm{di} a$, dependiendo de la ecuación predictiva de la TMB usada. EI NAF promedio fue inferior al nivel de actividad de mantenimiento. Conclusión: 
La alta prevalencia de actividades sedentarias y el bajo porcentual de individuos que atendieron las recomendaciones de actividad física indican que esos programas deben ser ajustados para que los individuos inscriptos puedan atender las recomendaciones, preferentemente, con monitorización objetiva. Las ecuaciones poblacionales específicas mejoran la estimativa final del GETD y NAF. Nivel de Evidencia l; Estudios diagnósticos - Investigación de un examen para diagnóstico.

\section{Descriptores: Ingestión de energía; Actividad motora; Ejercicio.}

\section{INTRODUCTION}

The legacy of the XXI century for humanity is the increase in life expectancy, which makes it possible to estimate that by 2050 more than two billion people in the world will be over 60 years old ${ }^{1}$. The projection is that by 2060 Brazil will have 73.5 million elderly people ${ }^{2}$. The rapid pace of an increasingly aging demographic profile means that Brazil needs to quickly adapt to this phenomenon. This inevitably implies that the country will have to make changes in social policies, particularly those aimed at meeting the growing demands in health, given that the elderly population demands greater attention because they present a higher prevalence of chronic diseases, physical disabilities, mental illnesses and other comorbidities, which in many cases are related to changes in their nutritional status ${ }^{1}$. Nutritional status imbalances, both under and over nutrition, increase health risks in the elderly and deserves specific care in this population ${ }^{3}$ and concern for governmental public policies ${ }^{4}$.

Some studies show that physical activity (PA) is important for improving functional capacity, cardiorespiratory and muscular capacities, bone health and reducing the risk of chronic diseases, depression and cognitive decline ${ }^{5}$. However, the sedentary lifestyle is very prevalent among the elderly in various parts of the world. According to data from the National Health Survey (PNS) ${ }^{6}$, conducted in 2013, 62.7\% of the Brazilian elderly were inactive and only $13.6 \%$ of the elderly met the recommended level of leisure-time PA (LTPA). This condition, associated with inadequate diet, is considered one of the most important risk factors for the onset of chronic diseases, particularly obesity 5 . The PNS data indicate that overweight (body mass index - BMI $\geq 25 \mathrm{~kg} \cdot \mathrm{m}^{-2}$ ) was around $67 \%$ and $58 \%$ and obesity (BMI $\geq 30 \mathrm{~kg} \cdot \mathrm{m}^{-2}$ ) in 28 and $24 \%$ of the Brazilian population aged between 65 74 and over $75 y$, respectively ${ }^{7}$. These data indicate an evident situation of positive energy balance (EB), energy intake (EI) $>E E$, in the Brazilian elderly population. Apparently, EE obtained from questionnaires, as frequently done in national surveys ${ }^{6}$, is not reliable ${ }^{8}$. For the description of the PA pattern, questionnaires may be valid for the identification of mild to moderate intensity activities, but may require evaluations of a large number of days ${ }^{9}$, which may be operationally problematic in the elderly.

In this context, the objective methods can more accurately describe the PA and EE patterns of the population and facilitate the monitoring of this information. To this end, the purpose of the present study was to assess the PA level (PAL) and total daily EE (TDEE) in a sample of elderly residents in the city of Niterói, Rio de Janeiro, Brazil.

\section{MATERIALS AND METHODS}

The present cross-sectional and observational study was carried out in a convenience sample of elderly individuals ( $\geq 60$ years of age) between September 2012 and March 2014 recruited from public social projects aimed to enhance PA in the elderly population of the city of Niterói. All research procedures were approved by the Research Ethics Committee of the Faculty of Medicine of Universidade Federal Fluminense, Antônio Pedro University Hospital (CAAE: 01774512.8.0000.5243) and the participation of the elderly occurred when he/she read and signed an Informed Consent.

The elderly who met the inclusion criteria (residence in the municipality of Niterói who were not diabetic and did not have cancer and hyper or hypothyroidism) were invited to participate in the project and instructed to come to the research laboratory at a previously scheduled day and time. Those who had asymmetry due to amputation, unilateral paralysis or neuromuscular conditions that reduced or impeded mobility were excluded. A total of 132 elderly people were recruited, of whom 97 accepted to participate in the study, but only 88 were included in this study because they met the criteria for the accelerometry analysis described later.

The elderlies came to the laboratory in one morning when anthropometric and body composition measurements were measured. Stature was obtained following standardization described in Lohman et al. ${ }^{10}$ in a wooden stadiometer. Body mass (BM) was obtained in a Filizola PL-200 electronic scale with an accuracy of $0.1 \mathrm{~kg}$ and BMI $\left(\mathrm{kg} \cdot \mathrm{m}^{-2}\right)$ was calculated as the ratio of $\mathrm{BM}$ and stature squared, allowing the classification of the nutritional status according to the cutoff points established by $\mathrm{WHO}^{11}$.

Fat-free mass (FFM) and fat mass (FM) were obtained by DXA (Lunar iDXA-General Electric Healthcare, Madison, WI), with the percentage of body fat (\% BF) derived from FM/BM x 100. Fat mass index (FMI) and fat-free mass index (FFMI) were derived from FM and FFM divided by squared stature, respectively. The diagnosis of excess fat and obesity was made with the FMI values as suggested by Kelly et al. ${ }^{12}$.

At the lab visit, each elderly received a triaxial accelerometer (Actigraph model GT3X, Pensacola, Florida, USA) and detailed instructions for their handling and use on the waist for seven consecutive days. After this period, the accelerometers were collected and the stored raw data were transferred to a microcomputer using the ActiLife v6.7.0 program (ActiGraph, Pensacola, Florida, USA) and converted to data files, in 60s epoch (counts per minute - CPM), for analysis. A valid day was established for a minimum of 10 hours of accelerometer use. The presence of an interval greater than 60 minutes with CPM values equal to zero in the magnitude vector of the three axes was considered as non-use. Only data from the elderly who had at least five valid days of monitoring were analyzed. The total number of accelerometry assessed days was 587 (426 and 161 days of the week and weekend days, respectively) in 88 elderly subjects ( 66 with seven days, 15 with six days and seven with five monitored days).

In addition to CPM the accelerometer data provided the total daily CPM sum and average. The sum of daily steps (DS) performed by individuals was also computed. As there is no consensus on CPM cutoff points to determine the intensity of activity performed by the elderly, CPM data were expressed across multiple CPM and DS ranges. The CPM cutoff points used for moderate PA were: 1) 1952 (Freedson et al. ${ }^{13}$ ); 2) 2020 (Troiano et al. ${ }^{14}$ ); 3) 809 (Hall et al. ${ }^{15}$ ); and 4) 1401 (Copeland \& Esliger ${ }^{16}$ ). CPM $<100$ was used as the criterion for sedentary activity. Days with 5000 DS were considered sedentary days, 7500 a "somewhat active" day and 10000 an "active" day"1. Additionally, the frequency of days in which the elderly reached 8000 DS was computed, because it is considered as the necessary number of DS for at least 30 minutes of moderate daily PA ${ }^{18}$.

The EE of each minute of the time that the accelerometer was used was calculated with the CPM data of a single axis (vertical) following the manufacturer's suggestion ${ }^{13}$. Basically, the process uses different prediction equations of EE based on the CPM value. For the time with CPM $=0$ with the accelerometer having been used, the resting EE estimation 
(MET) was calculated in two ways: 1) using the conventionally used $\mathrm{VO}_{2}$ value of $3.5 \mathrm{~mL} \cdot \mathrm{kg}^{-1} \cdot \mathrm{min}^{-1}\left(\mathrm{MET}_{\mathrm{e}}\right.$ ) and 2) the equations suggested by Anjos et al. ${ }^{19}$ for the adult population of Niterói $\left(M E T_{N}\right)$. For the sleeping duration, the MET value was multiplied by 0.95 , as suggested in the Compendium of Physical Activities ${ }^{20}$. When the equations of Freedson et al. ${ }^{13}$ provided EE values $<M E T$, the value of MET was used. The sum of the 1440 minutes of each day provided the TDEE, called TDEE for the value calculated using MET $\mathrm{T}_{\mathrm{e}}$ and $\mathrm{TDEE}_{\mathrm{N}}$ when MET $\mathrm{T}_{\mathrm{N}}$ was used in its calculation.

PAL, expressed as TDEE divided by the basal metabolic rate (BMR), was calculated with the TDEE $\mathrm{e}_{\mathrm{e}}$ and $\mathrm{BMR}\left(\mathrm{BMR}_{\text {schof }}\right.$ ) values estimated by the prediction equations of Schofield ${ }^{21}$, as suggested by FAO/WHO ${ }^{22}$, and with TDEE $_{N}$ values and BMR estimated by developed and validated equations $\left(B M R_{N}\right)$ to provide accurate and unbiased data for the adult population of Niterói i3. PAL was also calculated by dividing $T_{D E E_{e}}$ by $B M R_{N}$.

Descriptive statistical analysis was performed for the continuous variables. Comparisons between averages by sex were performed with Student's $t$ tests for the BMR and MET values estimated by the two equations and their TDEE and PAL derivatives for the whole sample, by sex and days of the week. An $a=0.05$ value was used to determine all significances. All analyzes were performed using SAS (Statistical Analysis Systems) software for microcomputer, v. 9.2.

\section{RESULTS}

The sample consisted of 88 elderly, mostly women $(n=72)$, with ages ranging from 60.1 to 84.3 years. Both men and women had a mean BMI above the adequacy range (Table 1). In fact, the prevalence of overweight was high, 36.4\% (36.1 and 37.5\% for women and men, respectively) and higher than that for obesity (25.0, 26.4 and 18.8\%, respectively). Using the FMI as the criterion for nutritional status, the prevalence of excess fat was 39.8, 37.5 and 50\% for the whole group, women and men, respectively. The prevalence of obesity was $28.4,29.1$ and $25.0 \%$, respectively. Both BMR and MET estimated by the specific equations for the population of Niterói were significantly lower than the values estimated by the equations traditionally used internationally.

Table 2 presents the values of PA results by accelerometry. The elderly spent an average of 600 min in sedentary activities, which represents between 66 and $68 \%$ of the waking hours, reaching approximately 15 hours. The average time for each cutoff varied greatly as expected. For males, CPM cutoff $\geq 1952$ meant an average of 30 min considering all assessed days and weekdays but not weekend days. For women, the CPM value to reach, on average, 30 min of activity would be between 1041 and 952 regardless of the day assesed. There was a difference of more than 1400 DS between the days of the week and weekend days. The total number of DS

Table 1. Physical and physiological characteristics of the elderly participants ( $\geq 60$ years of age) from Niterói, RJ.

\begin{tabular}{|c|c|c|c|c|}
\hline & \multicolumn{2}{|c|}{ Women $(n=72)$} & \multicolumn{2}{|c|}{ Men $(n=16)$} \\
\hline Variables $^{\mathrm{a}}$ & Mean $^{a}$ & SD & Mean & SD \\
\hline Age (years) & 69.2 & 5.8 & 67.8 & 4.0 \\
\hline Body mass $(\mathrm{kq})$ & 65.3 & 11.5 & 72.5 & 16.2 \\
\hline Stature $(\mathrm{cm})$ & 155.2 & 5.8 & 168.8 & 8.8 \\
\hline Body mass index $\left(\mathrm{kg} \cdot \mathrm{m}^{-2}\right)$ & 27.2 & 4.4 & 25.3 & 4.1 \\
\hline$\%$ body fat & $42.1^{*}$ & 5.4 & 29.2 & 7.0 \\
\hline Fat-free mass $(\mathrm{kg})$ & $37.6^{*}$ & 4.9 & 50.5 & 7.9 \\
\hline Fat mass $(\mathrm{kg})$ & $28.0^{*}$ & 7.6 & 22.0 & 9.2 \\
\hline Fat mass index $\left(\mathrm{kg} \cdot \mathrm{m}^{-2}\right)$ & $11.5^{*}$ & 3.1 & 7.7 & 2.8 \\
\hline Fat-free mass index $\left(\mathrm{kg} \cdot \mathrm{m}^{-2}\right)$ & $15.5^{*}$ & 1.5 & 17.6 & 1.8 \\
\hline \multicolumn{5}{|l|}{ Basal metabolic rate (BMR; kcal.day $\left.{ }^{-1}\right)^{b}$ : } \\
\hline $\begin{array}{c}\text { using Schofield (1985) equation }{ }^{21} \\
\end{array}$ & 1251.3 & 104.7 & 1436.9 & 190.0 \\
\hline using specific equation for the Niteroians ${ }^{23}$ & 1098.4 & 136.0 & 1290.0 & 208.2 \\
\hline \multicolumn{5}{|l|}{ Metabolic equivalent (MET; kcal.min $\left.{ }^{-1}\right)^{\mathrm{b}}$ : } \\
\hline $\mathrm{MET}_{\mathrm{p}}$ using $3.5 \mathrm{~mL} \cdot \mathrm{kq}^{-1} \cdot \mathrm{min}^{-1}$ & 1.14 & 0.20 & 1.27 & 0.28 \\
\hline $\begin{array}{l}\mathrm{MET}_{\mathrm{N}} \text { using the equation of } \\
\text { Anjos et al. (2011) }\end{array}$ & 0.86 & 0.10 & 0.99 & 0.14 \\
\hline
\end{tabular}

$\mathrm{SD}=$ Standard deviation. ${ }^{*} \mathrm{n}=71$. aAll variables significantly different between women and men, except for age. BMMR and MET estimates significatly different between used equations. was approximately 7000 and $23.9 \%$ and $17.6 \%$ of the elderly group could be considered as "somewhat active" and "active", respectively (Figure 1).

Table 3 presents the percentages of the days in which the elderly reached 30 min of moderate PA by the various CPM cutoff points and the number of DS. In general, the elderly presented percentage of days in which the recommendation was reached higher on the weekdays compared to the weekend days. Overall, approximately the elderlies would be sedentary in $36 \%$ of the days according to DS.

TDEE and PAL values of the elderlies are presented in Table 4. The highest TDEE value was found when the MET $\mathrm{e}_{\mathrm{e}}$ was used $\left(\mathrm{TDEE}_{\mathrm{e}}\right)$. TDEE

Table 2. Mean and standard deviation (SD) of activity expressed as counts of movement per minute (CPM) and number of daily steps in the 587 days monitored by accelerometry, by sex according to day of the week in the elderly ( $\geq 60$ years of age) sample from Niterói, RJ.

\begin{tabular}{|c|c|c|c|c|c|c|}
\hline & \multicolumn{2}{|c|}{ All } & \multicolumn{2}{|c|}{ Women } & \multicolumn{2}{|c|}{ Men } \\
\hline Variable & Mean & SD & Mean & SD & Mean & SD \\
\hline All days & \multicolumn{2}{|c|}{$\mathrm{n}=587$} & \multicolumn{2}{|c|}{$n=480$} & \multicolumn{2}{|c|}{$n=107$} \\
\hline CPM & 231.7 & 123.4 & 227.0 & 121.0 & 252.0 & 132.4 \\
\hline$\sum C P M$ & 209439 & 112831 & 205005 & 109527 & 229331 & 125231 \\
\hline \multicolumn{7}{|c|}{ Daily time (min) with CPM: } \\
\hline$<100$ & 600.2 & 114.6 & 596.2 & 114.2 & 617.9 & 115. \\
\hline$\geq 809$ & 73.9 & 44.8 & 73.0 & 45.6 & 78.2 & 40.8 \\
\hline$\geq 1041$ & 55.9 & 38.4 & 54.7 & 38.7 & 61.1 & 36.7 \\
\hline$\geq 1952$ & 23.2 & 26.7 & 21.6 & 26.1 & 30.2 & 28.2 \\
\hline$\geq 2020$ & 21.6 & 26.1 & 20.1 & 25.5 & 28.5 & 27.7 \\
\hline Waking time (min) & 904.3 & 104.9 & 902.4 & 105.3 & 912.8 & 102.9 \\
\hline$\%$ with $C P M<100$ & 66.4 & 10.5 & 66.1 & 10.5 & 67.8 & 10.2 \\
\hline$\sum$ Daily steps & 6946 & 3767 & 6907 & 3754 & 7120 & 3834 \\
\hline Weekdays & \multicolumn{2}{|c|}{$n=426$} & \multicolumn{2}{|c|}{$\mathrm{n}=349$} & \multicolumn{2}{|c|}{$\mathrm{n}=77$} \\
\hline CPM & 242.9 & 124.6 & 238.1 & 121.8 & 264.8 & 135.4 \\
\hline$\sum C P M$ & 219956 & 113392 & 215286 & 109310 & 241124 & 128976 \\
\hline \multicolumn{7}{|c|}{ Daily time (min) with CPM: } \\
\hline$<100$ & 595.3 & 113.6 & 591.5 & 112.5 & 612.2 & 117.8 \\
\hline$\geq 809$ & 78.6 & 45.4 & 77.8 & 46.1 & 82.5 & 41.8 \\
\hline$\geq 1041$ & 60.0 & 39.3 & 58.8 & 39.5 & 65.4 & 37.8 \\
\hline$\geq 1952$ & 25.4 & 27.8 & 23.6 & 27.3 & 33.6 & 28.5 \\
\hline$\geq 2020$ & 23.7 & 27.1 & 21.9 & 26.6 & 31.8 & 27.9 \\
\hline Waking time (min) & 906.6 & 105.0 & 905.6 & 105.8 & 911.4 & 101.5 \\
\hline$\%$ with $C P M<100$ & 65.7 & 10.3 & 65.3 & 10.3 & 67.2 & 10.4 \\
\hline$\sum$ Daily steps & 7333 & 3798 & 7304 & 3783 & 7464 & 3889 \\
\hline Weekend days & \multicolumn{2}{|c|}{$n=161$} & \multicolumn{2}{|c|}{$\mathrm{n}=131$} & \multicolumn{2}{|c|}{$\mathrm{n}=30$} \\
\hline CPM & 202.3 & 115.2 & 198.8 & 114.3 & 217.3 & 119.8 \\
\hline$\sum$ CPM & 181613 & 106770 & 177616 & 105714 & 199065 & 111406 \\
\hline & \multicolumn{6}{|c|}{ Daily time (min) with CPM: } \\
\hline$<100$ & 613.2 & 116.4 & 608.8 & 117.9 & 632.7 & 109.4 \\
\hline$\geq 809$ & 61.6 & 40.9 & 60.2 & 41.8 & 67.4 & 36.3 \\
\hline$\geq 1041$ & 44.9 & 33.7 & 43.7 & 34.1 & 49.9 & 31.8 \\
\hline$\geq 1952$ & 17.2 & 22.7 & 16.2 & 21.9 & 21.3 & 25.7 \\
\hline$\geq 2020$ & 16.1 & 22.2 & 15.2 & 21.4 & 20.0 & 25.4 \\
\hline Waking time (min) & 898.0 & 104.7 & 893.7 & 103.8 & 916.6 & 108.2 \\
\hline$\%$ with $C P M<100$ & 68.3 & 10.8 & 68.1 & 11.0 & 69.2 & 9.7 \\
\hline$\sum$ Daily steps & 5923 & 3491 & 5851 & 3476 & 6235 & 3601 \\
\hline
\end{tabular}

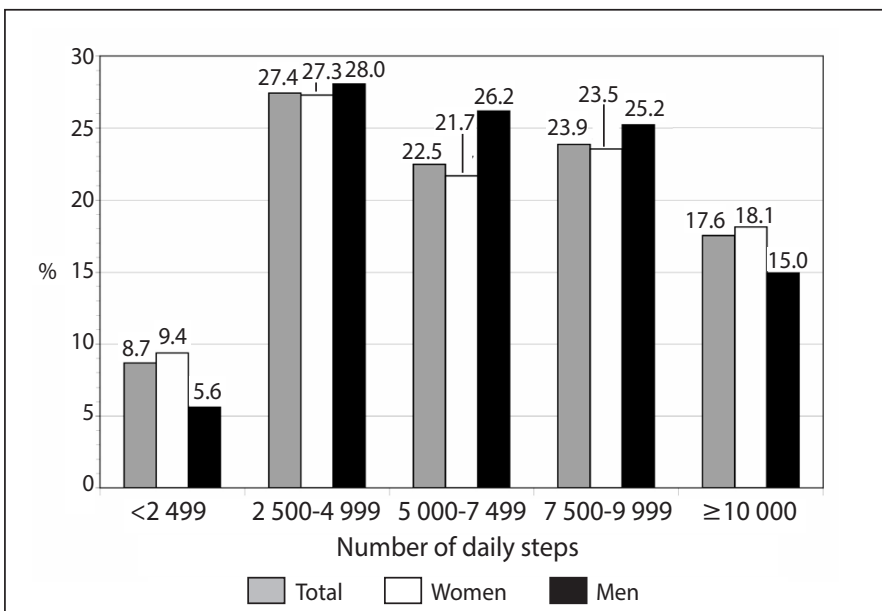

Figure 1. Distribution of daily steps in the 587 days assessed by accelerometry in the elderly ( $\geq 60$ years of age) sample from Niterói, RJ. 


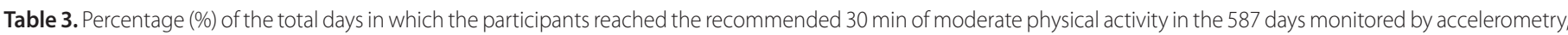
according to various CPM cutoff points or the number of daily steps by days of the week and sex in the elderly ( $\geq 60$ years of age) sample from Niterói, RJ.

\begin{tabular}{|c|c|c|c|c|c|c|c|c|c|}
\hline & \multicolumn{3}{|c|}{ All days } & \multicolumn{3}{|c|}{ Weekdays } & \multicolumn{3}{|c|}{ Weekend days } \\
\hline & All & Women & Men & All & Women & Men & All & Women & Men \\
\hline$n$ & 587 & 480 & 107 & 426 & 349 & 77 & 161 & 131 & 30 \\
\hline \multicolumn{10}{|c|}{ CPM cutoff points } \\
\hline$\geq 809$ & 86.4 & 85.4 & 90.6 & 89.0 & 88.5 & 90.7 & 79.5 & 77.1 & 90.0 \\
\hline$\geq 1041$ & 72.2 & 70.8 & 78.5 & 76.1 & 75.1 & 48.0 & 62.1 & 59.5 & 73.3 \\
\hline$\geq 1952$ & 30.0 & 27.9 & 39.2 & 34.5 & 31.5 & 48.0 & 18.0 & 18.3 & 16.7 \\
\hline$\geq 2020$ & 27.8 & 25.8 & 36.4 & 31.7 & 28.9 & 44.2 & 17.4 & 17.6 & 16.7 \\
\hline \multicolumn{10}{|c|}{ Daily steps } \\
\hline$<5000$ & 36.1 & 36.7 & 33.6 & 31.0 & 30.7 & 32.5 & 49.7 & 52.7 & 36.7 \\
\hline$\geq 7500$ & 41.4 & 41.7 & 40.2 & 47.0 & 46.7 & 48.0 & 26.7 & 28.2 & 20.0 \\
\hline$\geq 8000$ & 38.5 & 39.0 & 36.4 & 43.7 & 43.8 & 42.9 & 24.8 & 26.0 & 20.0 \\
\hline$\geq 10000$ & 17.6 & 18.1 & 14.9 & 20.2 & 20.9 & 16.9 & 10.6 & 10.7 & 10.0 \\
\hline
\end{tabular}

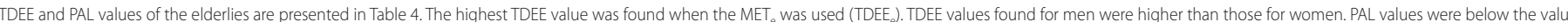
used for maintenance conditions (1.4) according to $\mathrm{FAO} \mathrm{WHO}^{24}$. PAL values only approximated 1.50 when it was calculated using the TDEE $\mathrm{E}_{e}$ divided by BMR

Table 4. Mean and standard deviation (SD) of total daily energy expenditure (TDEE) in the 587 days monitored by accelerometry and physical activity level (PAL) with basal metabolic rate (BMR) estimated by two equations in the elderly ( $\geq 60$ years of age) sample from Niterói, RJ.

\begin{tabular}{|c|c|c|c|c|c|c|}
\hline & \multicolumn{2}{|c|}{ All } & \multicolumn{2}{|c|}{ Women } & \multicolumn{2}{|c|}{ Men } \\
\hline Variables $^{b}$ & Mean & SD & Mean & SD & Mean & SD \\
\hline All days & \multicolumn{2}{|c|}{$(n=587)$} & \multicolumn{2}{|c|}{$(n=480)$} & \multicolumn{2}{|c|}{$(n=107)$} \\
\hline $\operatorname{TDEE}_{e}\left(\text { kcal.day }^{-1}\right)^{\mathrm{a}}$ & 1731.5 & 348.7 & 1690.0 & 304.9 & 1917.4 & 457.8 \\
\hline $\operatorname{TDEE}_{N}\left(\text { kcal.day }^{-1}\right)^{a}$ & 1356.3 & 223.7 & 1313.2 & 178.2 & 1549.7 & 295.1 \\
\hline \multicolumn{7}{|c|}{ PAL } \\
\hline $\mathrm{TDEE}_{\mathrm{e}} / \mathrm{BMR}_{\mathrm{schof}}$ & 1.34 & 0.14 & 1.34 & 0.14 & 1.32 & 0.16 \\
\hline $\mathrm{TDEE}_{\mathrm{N}} / \mathrm{BMR}_{\mathrm{N}}$ & 1.20 & 0.10 & 1.20 & 0.09 & 1.21 & 0.11 \\
\hline $\mathrm{TDEE}_{e} / \mathrm{BMR}_{\mathrm{N}}{ }^{\mathrm{a}}$ & 1.52 & 0.14 & 1.53 & 0.13 & 1.48 & 0.16 \\
\hline Weekdays & \multicolumn{2}{|c|}{$(n=426)$} & \multicolumn{2}{|c|}{$(n=349)$} & \multicolumn{2}{|c|}{$(n=77)$} \\
\hline $\operatorname{TDEE}_{e}\left(\text { kcal.day }^{-1}\right)^{\mathrm{a}}$ & 1740.9 & 354.7 & 1696.4 & 311.0 & 1942.6 & 458.8 \\
\hline $\operatorname{TDEE}_{N}\left(k^{\prime} c a l . d a y^{-1}\right)^{a}$ & 1366.3 & 230.2 & 1321.2 & 184.7 & 1570.9 & 297.0 \\
\hline \multicolumn{7}{|c|}{ PAL } \\
\hline $\mathrm{TDEE}_{\mathrm{e}} / \mathrm{BMR}_{\mathrm{schof}}$ & 1.34 & 0.14 & 1.34 & 0.14 & 1.34 & 0.16 \\
\hline $\mathrm{TDEE}_{\mathrm{N}} / \mathrm{BMR}_{\mathrm{N}}$ & 1.21 & 0.10 & 1.21 & 0.09 & 1.22 & 0.11 \\
\hline $\mathrm{TDEE}_{e} / \mathrm{BMR}_{\mathrm{N}}$ & 1.53 & 0.14 & 1.54 & 0.13 & 1.50 & 0.15 \\
\hline Weekend days & \multicolumn{2}{|c|}{$(n=161)$} & \multicolumn{2}{|c|}{$(n=131)$} & \multicolumn{2}{|c|}{$(n=30)$} \\
\hline $\operatorname{TDEE}_{e}\left(\text { kcal.day }^{-1}\right)^{\mathrm{a}}$ & 1706.3 & 332.0 & 1672.9 & 288.4 & 1852.5 & 456.4 \\
\hline $\operatorname{TDEE}_{N}\left(\text { kcal.day }^{-1}\right)^{\mathrm{a}}$ & 1329.8 & 203.9 & 1292.0 & 158.0 & 1495.2 & 287.7 \\
\hline \multicolumn{7}{|c|}{ PAL } \\
\hline $\mathrm{TDEE}_{\mathrm{e}} / \mathrm{BMR}_{\text {Schof }}$ & 1.32 & 0.13 & 1.33 & 0.13 & 1.29 & 0.16 \\
\hline $\mathrm{TDEE}_{\mathrm{N}} / \mathrm{BMR}_{\mathrm{N}}$ & 1.18 & 0.09 & 1.18 & 0.08 & 1.17 & 0.11 \\
\hline $\mathrm{TDEE}_{e} / \mathrm{BMR}_{\mathrm{N}}{ }^{\mathrm{a}}$ & 1.50 & 0.13 & 1.52 & 0.12 & 1.44 & 0.18 \\
\hline
\end{tabular}

$\operatorname{TDEE}_{e}=$ Total daily energy expenditure calculated using MET $\left(3.5 \mathrm{~mL} \cdot \mathrm{kg}^{-1} \cdot \mathrm{min}^{-1}\right) . \mathrm{GETD}_{\mathrm{N}}=$ Total daily energy expenditure calculated using $\mathrm{MET}_{\mathrm{N}}$ (Anjos et al. ${ }^{19}$ equation). $\mathrm{BMR}_{\text {schof }}=$ Basal metabolic rate calculated using Schofield ${ }^{21}$ equation. $B_{M R_{N}}=$ Basal metabolic rate calculated using the equation developed for the population of Niterói ${ }^{23}$. ${ }^{2}$ Significantly different between women and men. ${ }^{b}$ Estimated TDEE and PAL values significantly different between used methods.

values found for men were higher than those for women. PAL values were below the value used for maintenance conditions (1.4) according to FAO/WHO24. PAL values only approximated 1.50 when it was calculated

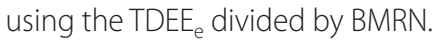

\section{DISCUSSION}

The debate about and the stimulation of the initiatives of promotion of PA have been increasingly frequent in the current Brazilian scenario of demographical, increase of the elderly population', and nutritional, increase in the prevalence of overweight/obesity ${ }^{7}$, profiles. In order to minimize the effects of this combination on chronic health conditions, depression and mobility limitations, the stimulus to meet the current recommendation of weekly 150 min of moderate to heavy PA is considered one of the priority actions for health promotion ${ }^{24}$. Thus, projects that provide activities for the elderly are becoming increasingly frequent in Brazilian municipalities, such as those in which the elderly in the present study were recruited in the city of Niterói.

One positive thing about the present study is that PA assessment was performed objectively by means of accelerometry for at least five days. However, there is no consensus on the classification of the intensity of moderate activity in the elderly. In general, the used CPM cutoffs are developed in studies that assess the energy cost of activities that would be associated with the intensity of 3 METs but they vary widely in the literature. Hall et al. ${ }^{15}$ suggested the CPM $\geq 809$ as the cut-off point for the lower limit of moderate activity in 20 elderly (61-90 years) walking at the speed of $2.4 \mathrm{~km} . \mathrm{h}^{-1}$. The 1041 value for moderate activity, suggested by Copeland \& Esliger ${ }^{16}$, was based on walking data at $3.2 \mathrm{~km} \cdot \mathrm{h}^{-1}$ in 38 elderly Canadians. CPM $\geq 1$ 952, the first cut-off point to be developed for the CSA accelerometer, precursor to the actigraph used in the present study, was derived by Freedson et al. ${ }^{13}$ in a study involving 50 young adults ( 25 of each sex) with mean age of 24.8 (males) and 22.9 years (females), when walking on a treadmill in three speeds: 4.8; 6.4 and 9.7 $\mathrm{km} \cdot \mathrm{h}^{-1}$. Troiano et al. ${ }^{14}$ developed a criterion based on the cut-off points of intensity of Freedson et al..$^{13}$ and three other studies that established CPM $\geq 2020$ for the activities equivalent to 3 METs and 5999 for those of heavy intensity ( $6 \mathrm{METS}$ ). Similarly, recent data question the commonly used cutoff point of CPM < 100 for sedentary lifestyle in the elderly using the Actigraph accelerometer at the waist. Koster et al. ${ }^{25}$ found a much lower value, CPM < 22 for sedentarism in 62 people aged 70 to 92 years of age. Therefore, cut-off points suggested by Freedson et al. ${ }^{13}$, widely used in the literature, may underestimate the activities of all intensities in the elderly. Van Holle et al. ${ }^{26}$ compared, in a sample of 434 elderly Belgians, the percentage that reached the recommendation of $150 \mathrm{mi}$ nutes per week according to the cut-off points of Freedson et al. ${ }^{13}$ and Copeland \& Esliger ${ }^{16}$ and showed that the second criterion identified a recommendation range higher than the first one by 2.6 times. Thus, until appropriated cutoff points are established for activities in the elderly, it is important that the data be expressed by the various suggested values so that comparisons be made between studies and populations. Using the cut-off point of Freedson et al. ${ }^{13}$, only men reached the mean time of 30 min of moderate PA, but only in approximately $40 \%$ of the days.

The study conducted by Ortlieb et al. ${ }^{27}$ in 168 elderly Germans showed that only $35.7 \%$ of their sample were able to achieve the recommendation of weekly 150 min of moderate activity. In the present sample of elderlies, similar percentage was found for the days in which the elderly reached the 30 min of moderate activity assessed by the number of DS. The mean number of DS required for the present sample of Niteroian elderly to reach 30 min of moderate to heavy activity was higher than the value of 8000 DS, as suggested by Tudor-Locke et al. ${ }^{18}$. The present sample of elderly people of Niterói needed more than 10000 DS to reach the 30 min of activity.

On the other hand, much interest has been given to the duration the population remains in sedentary activities. The percentage of time (64.5\%) in which a large sample of elderly Englishmen ${ }^{28}$ remained in sedentary activities was similar to that found in the elderlies in Niterói. The elderly spends much of their day in sedentary activities, of which 
screen time appears as the greatest marker ${ }^{29}$. Approximately 30\% of Brazilian individuals over 65 years of age from the most recent Vigite ${ }^{30}$ spend more than three hours a day watching television.

The values of MET and TDEE predicted from the suggested equations for the population of Niterói were lower than those calculated using the MET value traditionally used. The calculated PAL values were below the lower value of the $\mathrm{FAO} / \mathrm{WHO}^{22}$ moderate or sedentary lifestyle range (1.4 to 1.69), except when using the TDEE calculated with the traditional value of MET and BMR calculated using the equation developed for the population of Niterói. This value is more consistent with the pattern of activity found in the Niterói elderly sample and suggests that when estimating the TDEE in the elderly of Niterói, it is best to use the predicted BMR obtained by the equation proposed for the population of Niterói multiplied by the PAL of 1.5.

The present study presents some limitations, such as the absence of a gold standard method for the assessment of TDEE, the small sample size and the selection bias, due to the recruitment of the elderly enrolled in programs to encourage the practice of PA, which prevents results to be extrapolated to the general population. However, one can imagine that they can express the reality of the elderly who participate in such programs in the country.
In summary, the profile of higher prevalence of activities of sedentary intensity and the low number of elderlies that reached the recommendations indicate the need for more actions aimed at this public. Existing programs of activities for older people also need better targeting so that recommendations and their benefits can be achieved. In order to be successful, it is necessary to monitor the activities of the participants of these projects objectively, with accelerometry, for example. Pure participation in these programs may make the elderly feel they are active enough to benefit from the positive response of regular PA in health and disease prevention, which for most of the elderly in the present sample does not appear to be the case.

Apparently, the use of equations from samples of the population of interest seems to improve the final estimate of TDEE and consequently of EB, with the Actigraph accelerometer. It is evident that more studies on the energy cost and the intensity of the activities be carried out in association with accelerometry in the elderly so that cutoffs for the various intensities of activity are developed in this specific segment of the population.

All authors declare no potential conflict of interest related to this article

AUTHORS' CONTRIBUTIONS: Each author made significant individual contributions to this manuscript. LAA (0000-0002-5257-6912)* and VW (0000-0002-5563-3505)* planned the research, supervised data collection and conducted the analyses. BAMS (0000-0003-3066-0758)* collected the data and wrote a first draft of the manuscript which was reviewed, edited and approved by all authors who are responsible for all aspects of the final version of the work. *ORCID (Open Researcher and Contributor ID).

\section{REFERENCES}

1. Centro Internacional de Longevidade Brasil. Envelhecimento ativo: Um marco político em resposta à revolução da longevidade. 1a ed. Rio de Janeiro, RJ: Centro Internacional de Longevidade Brasil; 2015. Disponível em http://ilcbrazil.org/portugues/wp-content/uploads/sites/4/2015/12/Active-Ageing-A-Policy-Framework-ILC-Brazil_web.pdf.

2. Ervatti LR, Borges GM, Jardim AP. Mudança Demográfica no Brasil no Início do Século XXI - Subsídios para as projeções da população. Estudos e Análises. Informação Demográfica e Socioeconômica número 3. Rio de Janeiro: Instituto Brasileiro de Geografia e Estatística, Diretoria de Pesquisas, Coordenação de População e Indicadores Sociais; 2015. Disponível em: http://biblioteca.ibge.gov. br/visualizacao/livros/liv93322.pdf.

3. Leslie W, Hankey C. Aging, nutritional status and health. Healthcare (Basel). 2015;3(3):648-58.

4. Dias $P C$, Henriques $P$, Anjos LA, Burlandy L. Obesidade e políticas públicas: concepções e estratégias adotadas pelo governo brasileiro. Cad Saúde Pública. 2017;33(7):e00006016.

5. World Health Organization. Global Recommendations on Physical Activity for Health. Geneva:WHO; 2010.

6. Instituto Brasileiro de Geografia e Estatística. Pesquisa Nacional de Saúde. Percepção do estado de saúde, estilos de vida e doenças crônicas. Rio de Janeiro: IBGE; 2014.

7. Instituto Brasileiro de Geografia e Estatística. Pesquisa Nacional de Saúde. Ciclos de Vida. Brasil e Grandes Regiões. Rio de Janeiro: IBGE; 2015.

8. Colbert LH, Matthews CE, Havighurst TC, Kim K, Schoeller DA. Comparative validity of physical activity measures in older adults. Med Sci Sports Exerc. 2011:43(5):867-76.

9. Osti RFI, Garcia LMT, Florindo AA. Validation of the 24-hour physical activity recall in elderly adults. Rev Bras Cineantropom Desempenho Hum. 2014;16(1):15-26.

10. Lohman TG, Roche AF, Martorell R. Anthropometric standardization reference manual. Champaign, Illinois: Human Kinetics; 1988.

11. World Health Organization. Physical Status: the use and interpretation of anthropometry. Geneva:WHO; 1995.

12. Kelly TL, Wilson KE, Heymsfield SB. Dual energy X-Ray absorptiometry body composition reference values from NHANES. PLoS One. 2009;4(9):e7038.

13. Freedson PS, Melason E, Sirard J. Calibration of the Computer Science and Applications, Inc. accelerometer. Med Sci Sports Exerc. 1998;30(5):777-81.

14. Troiano RP, Berrigan D, Dodd KW, Mâsse LC, Tilert T, Mcdowell M. Physical activity in the United States measured by accelerometer. Med Sci Sports Exerc. 2008;40(1):181-8.

15. Hall KS, Howe CA, Rana SR, Martin CL, Morey MC. METs and accelerometry of walking in older adults: Standard versus measured energy cost. Med Sci Sports Exerc. 2013;45(3):574-82.

16. Copeland JL, Esliger DW. Accelerometer assessment of physical activity in active, healthy older adults. J Aging Phys Act. 2009;17(1):17-30
17. Tudor-Locke C, Camhi SM, Troiano RP. A catalog of rules, variables, and definitions applied to ac celerometer data in the National Health and Nutrition Examination Survey, 2003-2006. Prev Chronic Dis. 2012; 9:E113.

18. Tudor-Locke C, Leonardi C, Johnson WD, Katzmarzyk PT, Church TS. Accelerometer steps/day translation of moderate-to-vigorous activity. Prev Med. 2011;53(1-2):31-3.

19. Anjos LA, Machado JM, Wahrlich V, Vasconcellos MT, Caspersen CJ. Absolute and relative energy costs of walking in a Brazilian adult probability sample. Med Sci Sports Exerc. 2011;43(11):2211-8.

20. Ainsworth BE, Haskell WL, Herrmann SD, Meckes N, Bassett DR Jr, Tudor-Locke C, et al. 2011 Compendium of Physical Activities: a second update of codes and MET values. Med Sci Sports Exerc. 2011;43(8):1575-81

21. Schofield WN. Predicting basal metabolic rate, new standards and review of previous work. Hum Nutr Clin Nutr. 1985;39(Suppl 1):5-41.

22. FAO/WHO/UNU. Human energy requirements. Report of a joint FAO/WHO/UNU expert consultation Rome: FAO; 2004.

23. Wahrlich V, Teixeira TM, Anjos LA. Validity of a population-specific BMR predictive equation for adults from an urban tropical setting. Clin Nutr. 2018;37(1):208-13.

24. Jefferis BJ, Sartini C, Lee IM, Choi M, Amuzu A, Gutierrez C, et al. Adherence to physical activity guidelines in older adults, using objectively measured physical activity in a population-based study. BMC Public Health. 2014;14:382.

25. Koster A, Shiroma EJ, Caserotti P, Matthews CE, Chen KY, Glynn NW, et al. Comparison of Sedentary Estimates between activPAL and Hip- and Wrist-Worn ActiGraph. Med Sci Sports Exerc. 2016;48(8):1514-22.

26. Van Holle V, De Bourdeaudhuij I, Deforche B, Van Cauwenberg J, Van Dyck D. Assessment of physical activity in older Belgian adults: validity and reliability of an adapted interview version of the long International Physical Activity Questionnaire (IPAQ-L). BMC Public Health. 2015;15:433.

27. Ortlieb S, Gorzelniak L, Nowak D, Strobl R, Grill E, Thorand B, et al. Associations between multiple accelerometry-assessed physical activity parameters and selected health outcomes in elderly people-results from the KORA-age study. PLoS One. 2014;9(11):e111206.

28. Berkemeyer K, Wijndaele K, White T, Cooper AJM, Luben R, Westgate K, et al. The descriptive epidemiology of accelerometer-measured physical activity in older adults. Int J Behav Nutr Phys Act. 2016;13(1):2.

29. Hamer M, Stamatakis E. Screen-based sedentary behavior, physical activity, and muscle strength in the English longitudinal study of ageing. PLoS One. 2013;3;8(6):e66222.

30. Ministério da Saúde. Vigitel Brasil 2014. [Acesso em 29 jun 2016] Disponível em http://portalsaude. saude.gov.br/images/pdf/2015/abril/15/PPT-Vigitel-2014-.pdf. 